\title{
The Balancing of Safflower Oil and Inositol to Intestinal Morphometric of Sentul Chicken
}

\author{
Modawy Abdelgader Albasheer ${ }^{1,2}$, Ning Iriyanti ${ }^{1}$, Ismoyowati ${ }^{1 *}$ and Efka Aris Rimbawanto ${ }^{1}$ \\ ${ }^{1}$ Faculty of Animal Science, Jenderal Soedirman University, Purwokerto, Indonesia \\ 2Department of poultry, Faculty of Agriculture, Omdurman Islamic University, Khartoum, Sudan \\ *Corresponding author email: ismoyowati@unsoed.ac.id
}

\begin{abstract}
This study was aimed to evaluate the use of safflower oil (Carthamus tinctorius $L$ ) and inositol on the digestive profile of male Sentul chickens. A total of 182 Sentul chickens aged 17 weeks were reared up to 23 weeks in 91 units of battery cage (6 chickens/unit). The research was conducted in a Completely Randomized Design (CRD) with nine treatments and three replicates (6 chickens/replicate). The research treatments were R0 $=$ control/ basal feed $+0 \%$ Safflower and 0\% Inositol; R1 = Basal feed $+0.5 \%$ Safflower oil; R2 $=$ Basal feed + $1.0 \%$ Safflower oil; R3 $=$ Basal feed $+0.5 \%$ Inositol; R4 $=$ Basal feed $+1.0 \%$ Inositol; $R 5=$ Basal feed $+0.5 \%$ Safflower oil and 0.5\% Inositol; R6 = Basal feed + 0.5\% Safflower oil and 1.0\% Inositol; R7 = Basal feed + 1.0\% Safflower oil and $0.5 \%$ Inositol; R8 $=$ Basal feed $+1.0 \%$ Safflower oil and $1.0 \%$ Inositol. Basal feed was composed of corn, rice bran, soybean kernel, fishmeal, palm oil, calcium carbonate (CaCO3), topmix, lysine, and methionine, as well as safflower oil (Carthamus tinctorius $L$ ) and inositol. The measured variable consists of digestive profile (the percentage of intestine weight, digesta, proventriculus, gizzard) and intestine length, crypt depth, the width and length of intestinal villi, Intestinal histology profile. The data were subjected to a statistical analysis of variance (ANOVA) continued with an Honestly Significant Difference test (HSD). The result showed that incorporating safflower oil (Carthamus tinctorius $L$ ) and inositol into feed did not significantly affect $(P>0.05)$ the digestive profile of Male Sentul chickens. Conclusively, safflower oil and inositol up to $1 \%$ in the feed are safe for male Sentul chickens without interfering with the performance of digestive organs because it produces relatively similar intestinal weight and length, crypt depth, as well as the length and width of intestinal villi.
\end{abstract}

Keywords: safflower oil (Carthamus tinctorius L), inositol, intestinal villi

Abstrak. Tujuan penelitian untuk mengkaji penggunaan minyak safflower (Carthamus tinctorius $L$ ) dan inositol terhadap profil saluran cerna ayam sentul jantan. Materi penelitian yang digunakan adalah ayam Sentul jantan sebanyak 182 ekor umur 17 minggu yang dipelihara sampai umur 23 minggu pada kandang batere sebanyak 91 unit, dengan 6 ekor ayam/unit. Pakan basal yang tersusun dari jagung, dedak, bungkil kedelai, tepung ikan, minyak kelapa sawit, kalsium karbonat (CaCO3), topmix, lysin dan methionine, serta minyak safflower (Carthamus tincthorius $L$ ) dan inositol. Metode penelitian dengan Rancangan Acak Lengkap (RAL) 9 perlakuan dan 3 ulangan, dengan 6 ekor ayam/ulangan. Perlakuan Penelitian : $R_{0}=$ Kontrol/ pakan basal dengan $0 \%$ Safflower dan 0\% Inositol; $R_{1}=$ Pakan Basal + Minyak Safflower 0,5\%; $R_{2}=$ Pakan Basal + Minyak Safflower 1,0\%; $R_{3}=$ Pakan Basal + Inositol 0,5\%; $R_{4}=$ Pakan Basal + Inositol 1,0\%; $R_{5}=$ Pakan Basal + Minyak Safflower $0,5 \%$ dan Inositol 0,5\%; $R_{6}=$ Pakan Basal + Minyak Safflower 0,5\% dan Inositol 1,0\%; $R_{7}=$ Pakan Basal + Minyak Safflower $1,0 \%$ dan Inositol $0,5 \% ; R_{8}=$ Pakan Basal + Minyak Safflower 1,0 \% dan Inositol 1,0\%. Variabel yang diukur meliputi: profil saluran pencernaan (persentase berat usus, digesta, proventrikulus, gizzard) dan panjang usus, kedalaman crypt, lebar dan panjang vili usus) profil histologi usus. Data dianalisis secara statistik dengan analisis sidik ragam (ANOVA), dengan Uji lanjut uji Beda Nyata Jujur (BNJ). Hasil penelitian menunjukkan bahwa pemberian minyak safflower (Carthamus tinctorius $L$ ) dan inositol dalam pakan berpengaruh tidak nyata $(P>0,05)$ terhadap profil saluran cerna ayam sentul jantan. Kesimpulan Penggunaan minyak safflower dan inositol sampai level $1 \%$ dalam pakan ayam sentul jantan dapat digunakan sebagai imbuhan pakan untuk menjaga kesehatan ayam tanpa mengganggu kerja organ saluraan cerna dengan menghasilkan bobot dan panjang usus, kedalaman kripta, panjang dan lebar villi-villi usus yang relatif sama

Kata kunci: minyak safflower (Carthamus tinctorius $L$ ), inositol, villi-villi usus

\section{Introduction}

Sentul chickens can produce 85 to 210 eggs per year (Budiman et al., 2012). Another study reports that Sentul chickens can lay 26 eggs per period or around 150 eggs/year and they have a faster growth as well as better immune system 
against disease (Mugiyono et al., 2015; Isyanto et al., 2017). An optimum egg and meat production are the performance result of the digestive tract in producing digestive enzymes so that the nutrient absorption is optimum. The contributing factors to the level of nutrient absorption include conditions of intestinal villi, crypt depth as well as villi depth and width. The improvement of digestibility and nutrient absorption is significantly affected by the quality and role of the feed. Safflower oil (Carthamus tinctorius $L$ ) and inositol are feed supplements for improving the nutrient metabolism to achieve an optimum performance.

Safflower oil is plant-based oil obtained from the extraction of safflower seeds (Carthamus tinctoris L). Safflower oil contains high unsaturated fatty acid (90.33\%) and low saturated fatty acid (9.62\%). The highest concentrations of unsaturated fatty acid in safflower oil are $76.22 \%$ linoleic acid that belongs to the polyunsaturated fatty acid (PUFA) and $13.75 \%$ oleic acid that belongs to monounsaturated fatty acid (MUFA) (Ashrafi et al., 2010; Katkade et al., 2018). Safflower oil is rich in linoleic acid (75-78\%) that plays a crucial role in decreasing blood cholesterol as well as improving the performance, health status, nutritional value of starch, and the digestibility of crude fat and crude fiber. Safflower oil (Carthamus tinctorius) also contains omega- 6 and omega- 9 which, as reported by Maharani et al. (2018), exhibits secretion function in the digestion (omega-6), such as secreting acids and digestive enzymes. Safflower oil (Carthamus tinctorius) contributes some benefits because it contains $76.22 \%$ linoleic acids that promote nutrient digestibility. Diets with high linoleic acid cause changes in the morphology of the intestinal villi. Todorov et al. (2020) reported that mice fed a diet rich in $\alpha$-Linolenic acid (ALA) showed an increase in total ALA content along with changes in villus morphology. In particular, villus length increased in mice fed
ALA-rich diets, accompanied by an increase in mucosal thickness and the number of epithelial cells. The epithelial proliferation rate as well as the proportion of goblet and Paneth cells were significantly reduced in the ALA-rich diet group. An ALA-rich diet pushes the fatty acid composition of the intestinal tissue towards an anti-inflammatory phenotype. For example, a reduction in the dietary PUFA ratio $1-6 / 1-3$ is associated with a significant reduction in circulating levels of the pro-inflammatory marker interleukin- 6 as well as non-high-density lipoprotein (non-HDL) lipoprotein cholesterol in mice deficient in low density lipoprotein receptors (LDL).

Inositol belongs to the group of vitamin B8 and one of the vital biomolecules for growth, living, and reproduction. The symptoms of inositol deficiency include appetite loss and slow growth. Inositol may play a role in increasing body weight, performing biological functions in the body, sustaining cell growth and living, lipid metabolism, and insulin sensitivity, as well as increasing the absorption of mineral phosphor. The increased Myoinositol may also increase the phytase enzymes derived from the microbes of digestive tracts. The safflower is considered an immunological supplement to enhance immunity and improve productivity rather than adding growth stimulations. The combination of inositol and safflower oil as a dietary supplement could improve growth and promote the health of chickens to produce high quality meat and eggs.

Additionally, inositol also promotes body weight gain, plays vital biological functions together with tissues to synthesize and catalyze polyol. The physiological functions of particularly Myo-inositol include sustaining cell growth and living as well as the growth performance to increase the absorption of mineral phosphor. The research aimed to evaluate the use of safflower oil (Carthamus tinctorius $L$ ) and inositol on the digestive profile of male Sentul chickens. 


\section{Materials and Methods}

\section{Research Materials}

This study used 91 male Sentul chickens aged 4 (four) weeks and reared for 7 (seven) weeks. The basal feed was composed of corn, rice bran, soybean kernel, fishmeal, palm oil, calcium carbonate ( $\mathrm{CaCO} 3)$, topmix, lysine, and methionine, as well as safflower oil (Carthamus tincthorius L) (cold product, 100\%pure, Turkey) and inositol (Myo-Inositol from Sigma-Aldrich Chemie GmbH, Steinheim, Germany). The composition and nutrient content of treatment feed is presented in Table 1 and 2. A wire cage measuring $35 \times 35 \times 29 \times 56 \mathrm{~cm}$ was used to house two chickens. The other equipment included feed scales of $2 \mathrm{~kg} / 0.1 \mathrm{~g}$ and $1200 \mathrm{~g} / 0.1 \mathrm{mg}$.

\section{Research Method}

The research was conducted in a Completely Randomized Design (CRD) with nine treatments and three replicates (3 chickens each). The treatments were:

$\mathrm{R}_{0}=$ Control $/$ basal feed with $0 \%$ Safflower and $0 \%$ Inositol

$\mathrm{R}_{1}=$ Basal feed $+0.5 \%$ safflower oil

$R_{2}=$ Basal feed $+1.0 \%$ Safflower oil

$\mathrm{R}_{3}=$ Basal feed $+0.5 \%$ inositol

$\mathrm{R}_{4}=$ Basal feed $+1.0 \%$ inositol

$R_{5}=$ Basal feed $+0.5 \%$ safflower oil and $0.5 \%$ inositol
$R_{6}=$ Basal feed $+0.5 \%$ safflower oil and $1.0 \%$ inositol

$\mathrm{R}_{7}=$ Basal feed $+1.0 \%$ Safflower oil and $0.5 \%$ inositol

$R_{8}=$ Basal feed $+1.0 \%$ Safflower oil and $1.0 \%$ inositol

The feed ratio was composed on iso calorie and iso protein. The nutrient composition of feed is presented in Table 1.

\section{Research Undertaking \\ Cage preparation}

The cage was prepared by cleaning the whole cage and the perimeter as well as spraying disinfectant, spreading (dolomite) chalk, and fumigating with $\mathrm{KMNO} 4$ and formaldehyde. The cage and food and drinking water containers were sanitized. Additionally, the cage was made into partitions and each partition was randomly numbered.

\section{Basal Feed Formulation}

The feed was composed of corn, rice bran, fishmeal, soybean kernel, palm oil, lysin, $\mathrm{CaCO}$, methionine, and topmix. The mixture was added with safflower oil (Carthamus tinctoriusl) and inositol according to the level of treatment. The treatment feed was composed based on iso calorie and iso protein.

Table 1. Composition of feed for male Sentul chickens

\begin{tabular}{lccccccccc}
\hline \multirow{2}{*}{ Feedstuff } & $\mathrm{R}_{0}$ & $\mathrm{R}_{1}$ & $\mathrm{R}_{2}$ & $\mathrm{R}_{3}$ & $\mathrm{R}_{4}$ & $\mathrm{R}_{5}$ & $\mathrm{R}_{6}$ & $\mathrm{R}_{7}$ & $\mathrm{R}_{8}$ \\
\cline { 2 - 10 } & & & & & & $\%$ & & & \\
\hline Corn & 55 & 55 & 55 & 55 & 55 & 55 & 55 & 55 & 55 \\
Ricebran & 22 & 22 & 22 & 22 & 22 & 22 & 22 & 22 & 22 \\
Soybean kernel & 15 & 15 & 15 & 15 & 15 & 15 & 15 & 15 & 15 \\
Fishmeal & 5 & 5 & 5 & 5 & 5 & 5 & 5 & 5 & 5 \\
Palm oil & 0.5 & 0.5 & 0.5 & 0.5 & 0.5 & 0.5 & 0.5 & 0.5 & 0.5 \\
CaCO3 & 1 & 1 & 1 & 1 & 1 & 1 & 1 & 1 & 1 \\
Topmix & 0.5 & 0.5 & 0.5 & 0.5 & 0.5 & 0.5 & 0.5 & 0.5 & 0.5 \\
Lysin & 0.5 & 0.5 & 0.5 & 0.5 & 0.5 & 0.5 & 0.5 & 0.5 & 0.5 \\
Methionin & 0.5 & 0.5 & 0.5 & 0.5 & 0.5 & 0.5 & 0.5 & 0.5 & 0.5 \\
\hline Total & 100 & 100 & 100 & 100 & 100 & 100 & 100 & 100 & 100 \\
\hline Safflower oil & 0 & 0.5 & 1 & 0 & 0 & 0.5 & 0.5 & 1 & 1 \\
Inositol & 0 & 0 & 0 & 0.5 & 1 & 0.5 & 1 & 0.5 & 1 \\
\hline
\end{tabular}


Table 2. Nutrient composition of feed for male Sentul chickens

\begin{tabular}{|c|c|c|c|c|c|c|c|c|c|}
\hline \multirow{2}{*}{$\begin{array}{c}\text { Nutrient } \\
\text { composition }\end{array}$} & $\mathrm{R}_{0}$ & $\mathrm{R}_{1}$ & $\mathrm{R}_{2}$ & $\mathrm{R}_{3}$ & $\mathrm{R}_{4}$ & $\mathrm{R}_{5}$ & $\mathrm{R}_{6}$ & $\mathrm{R}_{7}$ & $\mathrm{R}_{8}$ \\
\hline & \multicolumn{9}{|c|}{$\%$} \\
\hline CP (\%) & 17.02 & 17.02 & 17.02 & 17.02 & 17.02 & 17.02 & 17.02 & 17.02 & 17.02 \\
\hline CFat (\%) & 7.96 & 7.96 & 7.96 & 7.96 & 7.96 & 7.96 & 7.96 & 7.96 & 7.96 \\
\hline CF (\%) & 4.16 & 4.16 & 4.16 & 4.16 & 4.16 & 4.16 & 4.16 & 4.16 & 4.16 \\
\hline $\begin{array}{l}\text { ME } \\
(\mathrm{kcal} / \mathrm{kg})^{*}\end{array}$ & 2.884 & 2.890 & 2.897 & 2.884 & 2.884 & 2.890 & 2.890 & 2.897 & 2.897 \\
\hline $\mathrm{Ca}(\%)^{*}$ & 1.28 & 1.2756 & 1.28 & 1.28 & 1.28 & 1.28 & 1.28 & 1.28 & 1.28 \\
\hline $\mathrm{P}(\%)^{*}$ & 0.38 & 0.3779 & 0.38 & 0.38 & 0.38 & 0.38 & 0.38 & 0.38 & 0.38 \\
\hline Lysin (\%)* & 1.11 & 1.1074 & 1.11 & 1.11 & 1.11 & 1.11 & 1.11 & 1.11 & 1.11 \\
\hline $\begin{array}{l}\text { Methionin } \\
(\%)^{*}\end{array}$ & 0.67 & 0.6708 & 0.67 & 0.67 & 0.67 & 0.67 & 0.67 & 0.67 & 0.67 \\
\hline
\end{tabular}

Note: Analysis result of Nutrition and Animal Feed Lab. UNSOED (2019)

*Calculated based on NRC Table (1994)

\section{Daily Rearing of Male Sentul chickens}

The maintenance included feeding in the morning and afternoon, and the water was provided ad libitum. The temperature and humidity were tracked and recorded every morning, midday, and afternoon. The male Sentul chickens were reared for two months, from eight weeks to 16 weeks old in the Experimental Farm, Animal Science Faculty, Jenderal Soedirman University, Purwokerto, Kabupaten Banyumas, Central Java. The data collection procedure was carried out by fasting the chickens for 6 hours, then each experimental unit was performed to 2 birds with body weight close to the average value. The chickens were slaughtered in accordance with Islamic law, followed by scalding, defeathering and evisceration. The internal organs were removed from the abdominal cavity, then the digestive tract was measured and observed.

\section{Data Analysis and Measurement}

The obtained data were subjected to analysis of variance (Steel et al., 1996). The Honestly Significant Difference test was conducted using SPSS ver 17.0 with a $5 \%$ error tolerance.

Digestive profile (the percentage of intestine weight, digesta, and intestine length, crypt depth, the width and length of intestinal villi, Intestinal histology profile (Iji et al., 2001). The crypt depth, intestinal villi length and intestinal villi width were analyzed descriptively.

\section{Results and Discussion}

The digestive tract is a vital organ for livestock because it is responsible for the digestibility and nutrient absorption of feed for wellbeing, production, and reproduction. When the digestive tract undergoes a disorder, it may negatively impact livestock performance.

The present study using safflower oil and inositol in the ration of male Sentul chickens showed its impact on the digestive profile as presented in Table 3.

Table 3 shows that safflower oil and inositol in the ration of male Sentul chickens does not significantly affect $(P>0.05)$ the digestive profile (intestine length and weight, digesta weight, crypt depth, the length and width of intestinal villi).

The result showed that despite the nonsignificant result, the treatments promoted the chickens' health and performance. Furthermore, it has quantitatively increased the digestive profile because the longer and heavier intestines would have more beneficial microbes (lactic acid bacteria) and produce more digestive enzymes. Additionally, the longer and 
Table 3. Digestive profile of Male Sentul chickens consuming feed fortified with safflower oil and inositol

\begin{tabular}{|c|c|c|c|c|c|c|}
\hline Treatments & IRW (\%) & RWID (\%) & IL $(\mathrm{cm})$ & $\mathrm{CD}(\mu \mathrm{m})$ & $\operatorname{IVL}(\mu \mathrm{m})$ & $\mathrm{IVW}(\mu \mathrm{m})$ \\
\hline $\mathrm{R}_{0}$ & $1.26 \pm 0.15$ & $3.27 \pm 0.13$ & $131.33 \pm 5.51$ & 831.73 & 1186.84 & 295.24 \\
\hline $\mathrm{R}_{1}$ & $1.84 \pm 0.14$ & $3.99 \pm 0.08$ & $161.00 \pm 21.52$ & 854.7 & 2170.39 & 432.16 \\
\hline $\mathrm{R}_{2}$ & $2.30 \pm 0.40$ & $3.33 \pm 0.11$ & $149.00 \pm 12.77$ & 951.46 & 2254.62 & 356.58 \\
\hline $\mathrm{R}_{3}$ & $2.13 \pm 0.19$ & $3.21 \pm 0.74$ & $156.33 \pm 12.86$ & 631.52 & 1585.23 & 319.82 \\
\hline $\mathrm{R}_{4}$ & $1.80 \pm 0.06$ & $3.16 \pm 0.40$ & $162.00 \pm 11.36$ & 752.15 & 2289.25 & 351.88 \\
\hline $\mathrm{R}_{5}$ & $1.78 \pm 0.18$ & $3.67 \pm 0.37$ & $145.33 \pm 5.69$ & 1191.55 & 2102.84 & 371.62 \\
\hline $\mathrm{R}_{6}$ & $1.99 \pm 0.30$ & $3.29 \pm 0.59$ & $149.00 \pm 3.46$ & 841.16 & 2321.24 & 395.36 \\
\hline $\mathrm{R}_{7}$ & $1.85 \pm 0.15$ & $3.68 \pm 0.05$ & $153.67 \pm 4.73$ & 311.12 & 2070.40 & 374.56 \\
\hline $\mathrm{R}_{8}$ & $1.83 \pm 0.24$ & $3.89 \pm 0.14$ & $149.67 \pm 6.26$ & 931.62 & 1608.12 & 314.34 \\
\hline Significance & ns & ns & Ns & & & \\
\hline
\end{tabular}

Note: IRW: intestinal relative weight; RWID: Relative weight of intestinal digesta; IL: Intestine length; CD: crypt depth; IVL: Intestinal villi length; IVW: Intestinal villi width

wider the villi, the more nutrient is absorbed which eventually improves chicken performance.

Feed nutrient digestibility and absorption may be affected by the surface area of intestinal epithelial, total folds, total villi, and microvilli that enlarge the absorption area, as well as the height and width of villi surface (Sugito, et al., 2007; Ibrahim 2008).

Vili enlarges the surface of small intestines and affects the process of nutrient absorption (Alfiansyah, 2011). Vili is where nutrients are absorbed, so the wider the villi the more nutrients are absorbed, thus increasing the growth of body organs and carcass (Asmawati, 2014). The increase of villi height in the small intestines is strongly correlated with the improved digestibility and absorbability because the enlargement of an absorption area expresses the smooth system of nutrient transport across the body (Awad et al., 2008).

It shows that safflower oil and inositol did not affect the profile of digestibility organ and chicken performance and did not distract the nutrient metabolism process. Safflower oil and inositol can be used as a feed supplement to promote the performance of digestive tract organs by maintaining the $\mathrm{pH}$, microbial content, enzyme activity, and intestinal peristalsis. Safflower oil in the ration is harnessed as an energy source. Safflower oil is derived from safflower seeds and its main content is unsaturated fatty acids: $13.75 \%$ oleic acid and $76.22 \%$ linoleic acid (Katkade et al., 2018).

The content of unsaturated fatty acid may inhibit the activity of lipoprotein lipase enzyme (LPL), decreasing lipogenesis, and increase lipolysis (Hidayat, 2015). Inositol belongs to B type vitamin (Indyk, et al., 2016) and provides vitamin $B$ in the glucose/carbohydrate metabolism. Inositol has nine stereoisomers but Myo-inositol is the most prevalent one in the biological system and functions as metabolite essentials.

Inositol containing vitamin B8 and incorporated in feed plays a role in the growth where body weight gain increases with the development of tissues and organs of digestive tracts. Setiadi et al. (2011) stated body internal organs develop with the increasing body weight because these organs have to balance the increasing body demand to maintain a normal condition. Linoleic and oleic acids contained in safflower oil will be carried by lipoproteins in the blood after being absorbed by the intestinal villi, then distributed to cells throughout the body including intestinal cells and the digestive organs themselves. Utari (2010) explains that linoleic acid can prevent cell membranes from being damaged. Cells that are properly preserved can have a positive impact on tissue 
development and health. The provision of inositol with vitamin B8 content has a role in growth. Corze and Soulage (2013) stated that inositol has a role as a growth promoter where it is involved as a phospholipid component of cell membranes that is related to cell growth and survival. Safflower oil and inositol supplementation plays a role in maintaining the health and growth of digestive tissues and organs.

The length of small intestines in poultry is varied according to the age, race, and type of feed. Intestine and other digestive tract is a complex organ that supports body metabolism, maintains body, skeleton, and nerve system immunity (Overland and Kjeldsen, 2002). The development and addition of total cells in the intestine are influenced by the rate at which chickens can obtain feed to fulfill the nutrient demand for their development (Geyra et al., 2001).

When feed is offered earlier, it may stimulate the development of these organs, increasing the digestive capacity and intestinal absorption. In the small intestines, peristalsis occurs, and it mixes the digesta with pancreatic and bile fluids. The contributing factors to the nutrient digestibility of small intestines are the inner surface area of intestines (folds, villi, and microvilli) and digesta transit time in the intestine (Rofiq, 2003).

Houshmand et al. (2012) reported that incorporating probiotic or organic acids into the ration of broiler chickens with low or high protein did not affect the relative weight and the length of small intestines. Similarly, Iriyanti and Hartoyo (2018) stated that supplementing symbiotics that contained Lactobacillus $s p$. did not affect the weight and the length of small intestines of Sentul chickens.

Furthermore, Hamdani et al. (2017) explained that the length and width of intestines may be affected by the surface, and the high-fiber feed may change the digestive rate in the poultry. In this case, the higher the crude fiber, the slower the digestive rate and nutrient absorption. Additionally, bodyweight significantly affects the intestine length of poultry. According to Gumilar and Pratama (2018), the expanding surface of the cell membrane would ease the secretion of digestive enzymes and improve digestibility.

The other contributing factor to nutrient content in the feed is the fiber. The common ration for chicken usually contains a similar level of fiber, so it produces similar intestine weight. It is reported that feed with high crude fiber would affect the digestive tract condition by increasing the weight and length of the intestines (Iyayi, 2005).

Peng et al (2016) stated that feed efficiency in poultry depends on the digestive tract, particularly the villi and crypt that play a vital role in nutrient digestibility. Similarly, Laudadio et al. (2012) reported that the higher the villi, the wider the area for absorbing nutrients and potentially increases the growth and metabolism rate. Furthermore, digestive capacity and nutrient absorption may be reflected from the villi/crypt ratio: the higher the ratio, the higher the digestibility and nutrient absorption.

Intestine weight is affected by the amount and development of villi. The villi of 2-months Sentul chickens are not well developed so the absorption activity is not optimum. Sklan (2001) reported that the weight of intestinal components is affected by the number of cells and the size of villi in the components. Villi size is influenced by the rate of chicken in obtaining feed. Furthermore, the contributing factor to the metabolic products of nutrient absorption is the number of villi in the small intestines against the weight and length of small intestines in Sentul chicken (Figure 1). 


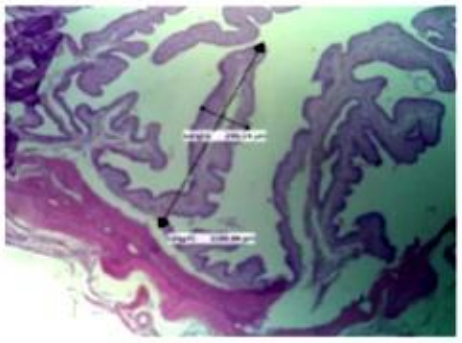

RO

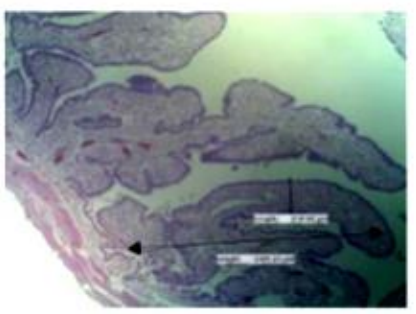

R3

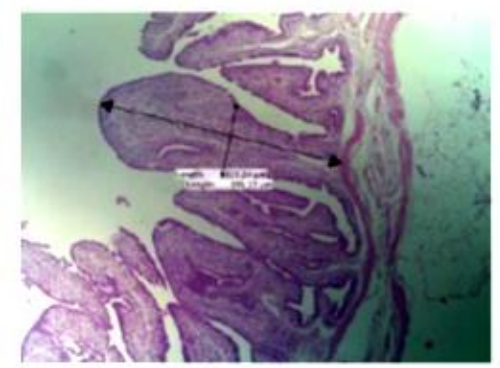

R6

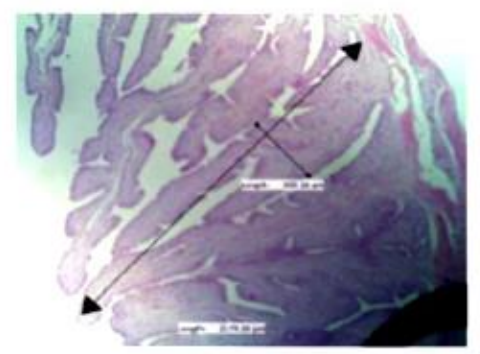

R1

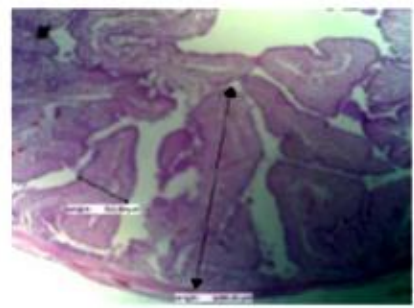

R4

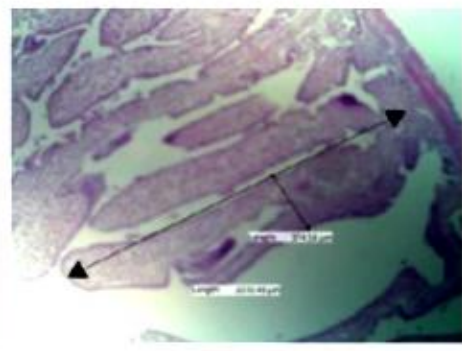

R7

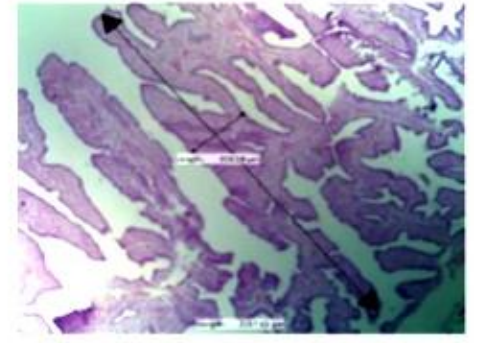

R2

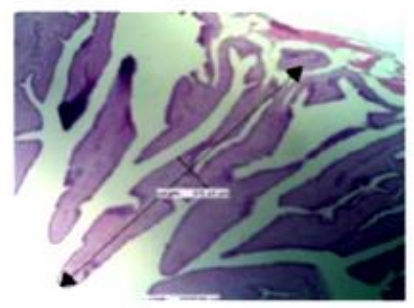

R5

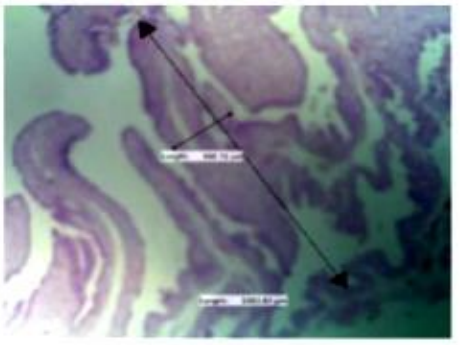

R8

Figure 1. Length and width of intestinal villi of Sentul chicken

Nutrient digestibility of small intestines is affected by the permeability values, the inner surface area of intestines (folds, villi, and microvilli), and the transit time of digesta in the intestines. Feed with a high crude fiber would affect the digestive tract conditions, namely increasing the weight and length of the intestine (lyayi, 2005).

According to Pardede (2018), nutrient balance in feed would affect the intestine length as well as intestine weight and body weight. Utama et al. (2019) reported that the more villi and goblet cells in the intestine would allow a perfect nutrient absorption because villi and goblet cells enlarge the intestinal surface and help the absorptive cells during the absorption process.

The condition of small intestines, such as villi height describes a larger area for absorbing nutrients (Awad et al., 2009). The increased height and width of villi are associated with a wider villi surface to absorb nutrition into the bloodstream (Mile et al., 2006). Furthermore, Awad et al. (2008) stated that the increased villi height in the small intestines of broiler chickens is strongly correlated with digestibility and absorbability because the enlarged absorption area expressed the smooth system of nutrient transport across the body that benefits the host. 


\section{Conclusions}

Safflower oil and inositol up to $1 \%$ incorporated into the feed of male Sentul chickens are the potential feed additives to maintain chicken health without upsetting the performance of digestive organs. The supplement produces relatively similar intestine weight and length, crypt depth, and villi length and width.

\section{Acknowledgement}

The authors express their gratitude to the Director of DRPM-DIKTI for the research grant through the Doctorate dissertation grant No. 042/SP2H/AMD/LT/DRPM/2020 of the budget year of 2020.

\section{References}

Alfiansyah, M. 2011. Anatomy and Digestion of small intestines. http://www. sentra-edukasi.com/. Accessed on 20 February 2017.

Ashrafi, E, and K Razmjoo. 2010. Effect of irrigation regimes on oil content and composition of safflower (Carthamus tinctorius $L$ ) cultivars. J Am. Oil. Chem. Soc. 87: 499-506.

Asmawati. 2014. The Effect of in ovo feeding on hatching weight and small intestinal tissue development of native chicken. Dissertation. Postgraduate Program, Hasanuddin University, Makassar

Awad, WA, K Ghareeb, S Nitclu, S Pasteiner, SA Raheem and J Bohm. 2008. Efect of dietary inclusion of probiotic, prebiotic and symbiotic on intestinal glucose absorb'tion of broiler chickens. Lrt. J. Poult. Sci. 7: 688-691.

Budiman, R. 2007. The Effect of garlic powder supplement on the blood profile of local chicken infected with nematode worms (ascaridia galli). Department of Nutrition and Livestock Feed Science. Faculty of Animal Science. Bogor. Bogor

Corze, ML, and CO Soulage. 2013. Potential role and therapeutic interests of myo-inositol in metabolic diseases. Journal Biochimie 95: 1811-1827.

Geyra, A, Z Uni, and D Sklan. 2001. The Effect of fasting at different ages on growth and tissue dynamics in the small intestine of the young chick. British Journal of Nutrition, 86(1), pp.5361.

Gumilar, J, and A Pratama. 2018. Production and characteristics of halal gelatine made of chicken intestines. Journal of Agroindustrial Technology, 28(1).

Hamdani, MDI, BF Dewantara, Sulastri and K Adhianto. 2017. The characteristics and composition of poultry carcass. Faculty of Animal Science. Lampung University. Lampung

Hidayat, C. 2015. The depleting deposit of abdominal fat of broiler chickens through feed management. Wartazoa 25(3): 125-134.

Houshmand, M, K Azhar, I Zulkifli, M H Bejo, and A Kamyab. 2012. Effects of non-antibiotic feed additives on performance, immunity and intestinal morphology of broilers fed different levels of protein. Afr. J. Anim. Sci. 42 (1): $22-32$

Ibrahim, S. 2008. The correlation of smal intestine size and body weight of broiler chickens. Agripet : Vol (8) No. 2: 42-46.

Iji, PA, RJ Hughes, M Choct and DR Tivey. 2001. Intestinal structure and function of broiler chickens on wheat-based diets supplemented with microbial enzyme. Asian-Aust. J. Anim. Sci. 14(1):54-60.

Indyk, H E, S C Saldo, P M White, M N Dole, B D Gill and D C Woollard. 2016. The free and total myoinositol contents of early lactation and seasonal bovine milk. International Dairy Journal, 56, pp.33-37.

Iriyanti, N and B Hartoyo. 2018. The condition of digestive organs and immunity function of male sentul chickens supplemented with "fermeherbafit- encapsulasi". In Proceedings of Seminar of Livestock Technology and Agribusiness. 256-261. Universitas Jenderal Soedirman. Purwokerto

Isyanto, AY, Sudrajat and M Iskandar. 2017. The Development Strategy of Sentul Chickens in Ciamis Regency. Jurnal Pemikiran Masyarakat Ilmiah Berwawasan Agribisnis 3(1); 1-12.

Iyayi EA, O Ogunsola and R ljaya. 2005. Effect of three sources of fibre and period of feeding on the performance, carcase measures, organs relative weight and meat quality in broilers. International Journal of Poultry Science, 4(9): 695- 700

Katkade, MB, HM Syed, RR Andhale and MD Sontake. 2018. Fatty acid profile and quality assessment of safflower (Carthamus tinctorius) oil. journal of pharmacognosy and phytochemistry. 7 (2): 3581-3585.

Laudadio, V, L Passantino, A Perillo, G Lopresti, G Passantino, RU Khandan and V Tufarelli. 2012. Productive performance and histological feature sof intestinal mucosa of broiler chickens fedd ifferent dietary protein levels. Journal of Poultry Science. 91(1):265-270

Maharani, D, LD Mahfudz and I Mangisah. 2018. The effect of liquid waste of fish brine incorporated in 
the ration on protein and fat digestibility and metabolic enery on mojosari-peking crossbred duck. Jurnal Peternakan Indonesia. 20(1): 21-28.

Mile, RD, GD Butcher, PR Henry, and RC Littell. 2006. Effecf of antibiotic growth promoters on broiler performance, intestinal growth parameters, and quantitative morphology. J. of Poult. Sci. 85: 476485.

Mugiyono, S, DM Saleh, and Sukardi. 2015. Reproductive performance of various breeds of sentul chicken. Animal Production. 17 (3): 169176.

Overland, M and KC Kjeldsen. 2002. Safety of new approved performance enhancer. formi. Workshop. BASF. Form and Food Safety. Ludwigshafel, Germany.

Pardede, A, MF Harahap, and M Hasibuan. 2018. Coffee husk waste (Coffea arabica I) in the ration on the performance of quails (Coturnix coturnix Javonica). Jurnal Peternakan (Jurnal of Animal Science), 1(2), pp.43-48.

Peng, Q, XF Zeng, JL Zhu, S Wang, XT Liu, CL Hou, PA Thacker and SY Qiao. 2016. Effects of dietary lactobacillus plantarum B1 on growth performance, intestinal microbiota, and short chain fatty acid profiles in broiler chickens. Poult. Sci. 95: 893-900. http://dx.doi.org/10.3382/ps/pev435.

Rofiq, MN. 2003. The effect of indigenous materialbased feed on the performance of small intestinal villi of broiler chickens. Jurnal Sains and
Teknologi Indonesia,5(5), pp.190-194.

Setiadi, D, K Nova, and Tantalo 2011. The comparison of liveweight and the weight of carcass, giblet and abdominal fat of medium-type roosters from different strains fed on commercial broiler feed. Jurnal peternakan. 2(3):10-17

Sklan, D. 2001. Development of the digestive tract of poultry. World's Poultry Science Journal, 57(4), pp.415-428.

Steel, RGD, JH Torrie, and DA Dickey. 1996. Principles and procedures of statistics: A biometrical approach. McGraw-Hill, New York.

Sugito, MW, DA Astuti, E Handharyani, and Chairul. 2007. Liver and kidney histopathology of broiler chickens exposed to heat stroke and supplemented with willow bark extract (Salix tetrasperma Roxb). JITV. 12:6873.

Todorov, H, B Kollar, F Bayer, I Brandão, A Mann, J Mohr, and C Reinhardt. 2020. $\alpha$-Linolenic acidrich diet influences microbiota composition and villus morphology of the mouse small intestine. Nutrients, 12(3), 732.

Utama, CS, B Sulistiyanto, and TA Wicaksono. 2019. The effect of processed pollard on the growth of digestive organs of seven-weeks broiler chickens. Jurnal Litbang Provinsi Jawa Tengah, 17(1), pp.101-110.

Utari, DM. 2010. Kandungan asam lemak, zink, dan copper pada tempe, bagaimana potensinya untuk mencegah penyakit degeneratif. Jurnal Gizi Indonesia. 33(2): 105115. 